\title{
In memoriam Manfred te Grotenhuis (1967-2018)
}

\author{
Peer Scheepers Q Joris Kregting*
}

Op vrijdagavond 12 oktober 2018 overleed op 51-jarige leeftijd Manfred te Grotenhuis, na een ziekbed van slechts vier maanden. Manfred was universitair docent kwantitatieve methodologie, in het bijzonder data analyse, binnen de afdeling Sociologie van de Radboud Universiteit Nijmegen. De godsdienstsociologie behoorde tot één van Manfreds voornaamste onderzoeksvelden.

Manfred promoveerde in 1999 op zijn proefschrift Ontkerkelijking: oorzaken en gevolgen waarin het Nederlandse secularisatieproces werd beschouwd op basis van uiterst degelijk kwantitatief empirisch onderzoek. Talrijke artikelen volgden over secularisatie in Nederland maar ook in andere Westerse landen. Hij schreef artikelen met verklaringen voor secularisatie, bijvoorbeeld rationalisatie en sociale zekerheid, welke werden gepubliceerd in The Journal for the Scientific Study of Religion (2001; 2008; 2010), Sociology of Religion (2002), Review of Religious Research (2008), European Sociological Review (2015) en Mens \& Maatschappij (2005; 2011). Verder schreef hij artikelen over de gevolgen van secularisatie, bijvoorbeeld als het gaat om sociaal kapitaal, cultuur en politiek, welke werden gepubliceerd in Review of Religious Research (2006) en Religie a Samenleving (2012; 2013). Daarenboven schreef hij, als co-auteur, een fraai artikel over religie en zelfmoord, dat werd gepubliceerd in American Sociological Review (2005). Veel van deze artikelen kwamen tot stand door samenwerking met zijn Nijmeegse vakgenoten: Manfred zocht de samenwerking steeds op met anderen die complementaire inzichten hadden. Manfreds grote kennis van het Nederlandse secularisatieproces droeg in 2013 sterk bij aan de organisatie van het publiekssymposium van dit tijdschrijft hetgeen resulteerde in de omvangrijke bundel Ontkerkelijking, nou en...? Oorzaken en gevolgen van secularisatie in Nederland (Religie \& Samenleving, jaargang 8 , nr. 1).

\footnotetext{
* Peer Scheepers is hoogleraar Methodologie van de Faculteit der Sociale Wetenschappen aan de Radboud Universiteit Nijmegen.

Joris Kregting is onderzoeker bij Kaski, onderdeel van de Faculteit der Filosofie, Theologie en Religiewetenschappen aan de Radboud Universiteit Nijmegen.
} 
In zijn godsdienstsociologische werk als onderzoeker liet hij zich graag inspireren door klassieke sociologen, maar hij was ook goed op de hoogte van eigentijdse sociologische theoretici. Zijn werk kenmerkte zich door een compromisloos zoeken naar robuuste wetenschappelijke inzichten vooraleer die kennis te boekstaven.

Naast de godsdienstsociologie lag Manfreds onderzoekspassie bij de statistiek. Zijn proefschrift behandelde al hoe leeftijds-, periode- en cohorteffecten zich tot elkaar verhouden, geillustreerd aan de hand van kerkbezoek in Nederland tussen 1970 en 1995. Talrijke methodologische artikelen volgden, vaak geschreven met zijn Nijmeegse geestverwanten Rob Eisinga en Ben Pelzer, die werden gepubliceerd in gerenommeerde tijdschriften als International Journal of Epidemiology (2011) en Demography (2015). Zijn recente publicatie in International Journal of Public Health (2016) over betrouwbaarheidscoëfficiënten behoort volgens ResearchGate tot de top-10 meest geraadpleegde artikelen van de Radboud Universiteit Nijmegen. Velen raadplegen tot op de dag van vandaag Manfreds video's over statistiek op zijn eigen Youtubekanaal.

Manfred was een begenadigd en gelauwerd docent. Hij verzorgde een groot aantal cursussen op het gebied van statistiek en geavanceerde methoden voor uiteenlopende groepen studenten in de maatschappijwetenschappen. Dat waren intensieve cursussen die door studenten vaak als lastig werden ervaren. Hij beleefde er groot intrinsiek plezier aan om zo veel mogelijk studenten mee te nemen en inzichten bij te brengen op zijn vakgebied. Daarom werden zijn cursussen door studenten zeer positief geëvalueerd. De door hem ontwikkelde didactische methodes op het gebied van de statistiek zijn geboekstaafd in het Nederlands ( 3 boeken) en in het Engels (eveneens 3 boeken). Binnen het Nederlandse taalgebied behoren zij tot de meest verkochte boeken op dit terrein.

Hij was enorm trots op de erkenningen die hij voor zijn onderwijs kreeg. In 2009 heeft de Faculteit der Sociale Wetenschappen hem de Facultaire Onderwijsprijs toegekend en in 2010 heeft het college van bestuur van de Radboud Universiteit hem met de Universitaire Onderwijsprijs gelauwerd. Daarnaast werd hij in 2014 door de Radboud Universiteit genomineerd voor de prestigieuze Wharton Prijs voor innovatief wetenschappelijk onderwijs. Toen hij in het voorjaar van 2018 een bijzonder positieve evaluatie kreeg voor de cursus Regressie Analyse - een 9,9 voor zijn prestaties als docent -, zal hij 
in stilte gegniffeld hebben, maar hij zal ook gedacht hebben: 'Er is nog ruimte voor verbetering'. Recentelijk werd hij door de studenten Sociologie nog gekozen tot Docent van het Jaar.

Manfred was een onconventionele collega: als student en later als aio kleedde hij zich alsof hij lid was van een motorclub. Zelfs bij een recente voordracht, voor het college van bestuur en het college van decanen, verscheen hij geheel in eigen stijl, hoewel hij een kostuum op zijn kamer had hangen voor academische plechtigheden. Hij dwong desalniettemin enorm veel respect af door zijn wetenschappelijke habitus, streven naar kwaliteit en de door hem voorgeleefde wetenschappelijke integriteit.

Manfred had een tomeloze inzet als het ging om zijn werk, tot vrijwel het laatste moment van zijn leven. Hij stierf min of meer in het harnas. Ondanks zijn snel verslechterende toestand, bleef hij zeer nauw betrokken bij een van zijn geesteskinderen, de cursus Toetsende Statistiek, tot in het weekend voor zijn overlijden. Hij wilde zijn werk niet loslaten en bleef constructief meedenken over mogelijke verbeteringen in het onderwijs, zelfs op zijn sterfbed, soms met een traan in zijn ooghoeken, meestal met een lach op zijn lippen. Kort voor zijn dood wilde hij nog per se samen de laatste hand leggen aan een bijzonder innovatief wetenschappelijk artikel dat postuum gepubiceerd zal worden. Zijn 'zwarte humor' en relativeringsvermogen hielden hem tot in zijn laatste dagen op de been totdat het moment aanbrak dat hij zich moest overgeven aan de medicatie.

Onze gedachten gaan uit naar Anita, zijn vrouw, en hun kinderen, Tommy en Lotte, die hem zullen moeten missen. Ook leven we mee met zijn broer Harald, die hem broederlijk steunde in de laatste maanden, zijn moeder en zijn verdere naaste familieleden. Wij hopen hen bij te kunnen staan bij de verwerking van het verlies van deze bijzondere man. 